\title{
Prevalence of chickenpox in primary school children in Baquba city
}

\author{
Sarmad Yahya Abbood (MD, FICMS) ${ }^{1}$, Saad D Hameed (MD, FICMS) ${ }^{2}$ and \\ Wathik M Hussein (MD, FICMS) ${ }^{3}$ \\ ${ }^{1}$ Department of Dermatology and Venereology, Baquba Teaching Hospital, Diyala,Iraq \\ ${ }^{2}$ Department of Dermatology and Venereology, Baquba Teaching Hospital, Diyala,Iraq \\ 3 Department of Dermatology and Venereology, Baquba Teaching Hospital, Diyala,Iraq \\ Correspondence Address: \\ Saad D Hameed \\ Department of Dermatology and Venereology, Baquba Teaching Hospital, Diyala,Iraq \\ email: Sum_sum112233@yahoo.com
}

Received: 25 April 2021

Accepted: 26 September 2021

Published: 25 December 2021

Diyala Journal of Medicine 2021:21(2): 70-75

\begin{abstract}
Background: Chickenpox is a viral disease caused by a virus called Varicella Zoster Virus $(\mathrm{VZV})$. It is more prevalent among children less than 10 years.

Objective: To estimate the prevalence of chickenpox among the different age groups and monthly distribution per year in Baquba city sectors recorded in Baquba teaching hospital.

Patients and Methods: Data was collected of 82 patients from $1^{\text {st }}$ January -31 th July 2019, and the statistical data was recorded as name, age, sectored where patients' lives.

Results: Eighty-two patients with chickenpox data were collected in Baquba teaching hospital, male $52(63.4 \%)$, and female $30(36.5 \%)$ of cases in different age groups, were highest prevalence in(9-12) years age group (30) cases, and lowest in cases older than 12 years old were (6) cases reported, t-test (2.671).

Conclusion: Chickenpox more common in male, highest infections were reported in winter months.
\end{abstract}

Keywords: Chickenpox, Varicella-Zoster Virus, children

DOI: https://doi:10.26505/DJM.21026000425 , (CAuthors, 2021, College of Medicine, University of Diyala.

This is an open access article under the CC BY 4.0 license (http://creativecommons.org/licenses/by/4.0/) 


\section{Introduction}

Varicella-Zoster Virus (VZV) (HHV3) is the etiology of Varicella (chickenpox).Varicella is usually symptomatic, and before the advent of the Varicella Vaccine, it occurred in $90 \%$ of children in US by the time they reached 10 years of age, and approximately 4 million cases occurred annually in the US [1], with large outbreaks during the winter and spring, but it may see at any time of the year. In Iraq the Chickenpox is considered a monthly noticeable disease. Airborne droplets are the usual route of transmission of Varicella, and less commonly by direct contact with the lesions. The severity of the disease is age dependent, with adult having more severe disease and greater risk of Varicella disease. In healthy children the death rate from Varicella is 1.4 in 100,000 cases; in adult, 30.9 in 100,000 cases [2,3] . Chickenpox is more fatal in pregnant women than in the non- pregnant as five times [3]. Rare complications may be by Varicella or secondary bacterial infection with Staphylococcusaureus or Streptococcus organism, pneumonia is uncommon in normal children but 1 in 400 adults with Varicella [2]. Cerebellar ataxia and encephalitis are the most common neurological complications, others myocarditis, hepatitis, Reye syndrome, purpura fulminant [4]. The eruption of pruritic, erythematous macules and papules, starting on the scalp and face, then spreading to the trunk and extremities, the eruption beginning centrally, and spreading peripherally[5]. An attack of chickenpox usually confers lifelong immunity [6].Varicella vaccine is effective and approved for use in children and adults, FDA approved in 1995 (Oka strain, varivax). Two doses of the vaccine, given at ages 12-15 months, and 4-6 years [7]. The live attenuated VZV vaccine is contraindicated during pregnancy and in individuals with immunosuppression due to hematological malignancy, HIV infection, or systemic immunosuppressive therapy [7, 8].

\section{Patients and Methods}

A retrospective study was done, including all patients with chickenpox whom were recorded in outpatient clinic (dermatological clinic) in Baquba teaching hospital (Diyala) started from first January until the end of July 2019.

The information done by special questionnaire, include of name, age, sex, date of infection, residency. The diagnosis was done by dermatologist depending on clinical sign and symptom of the disease. Eighty-two patients were recorded included 52 male and 30 female.

\section{Statistical analysis}

The statistical analysis was done by Excell 2010, SPSS version 20 statistical program. The analysis was done by number, percent, ratio, and proportion as descriptive study.

\section{Results}

Eighty-two patients with chichenpox recorded in Baquba teaching hospital from $1^{\text {st }}$ January to $31^{\text {th }}$ July in 2019. Data were collected in department of dermatology in that hospital, $52(63.4 \%)$ male, 30(36.5\%) female of cases, t-test (3.723), Table (1).

The highest reported cases were observed in AL-tahrir sector which were (22) cases represent $(26.8 \%)$ of the total cases. While 
the lowest reported cases were observed in New Baquba 10 cases $(12.1 \%)$. t-test $(2,352)$, Table (2).

Highest VZV cases were observed in the (9-12) years of age group (30) cases represent $(36.5 \%)$.While lowest reported cases in the older than the 12 years old age group (6) cases which represent $(7.3 \%)$, t-test (2.671), Table (3).More cases of VZV

reported in January which were (32)cases (39.02\%), then in February were (25) cases $(30.4 \%)$ of the reported cases. In cold winter months, VZV infection cases were appears and they disappear toward the summer months, the lowest infection of cases reported in the April, May, June, and July 2019,Table (4).

Table (1): Frequency, distribution according to sex

\begin{tabular}{|c|c|c||}
\hline Sex & Number of cases & $\%$ \\
\hline \hline Male & 52 & 63.4 \\
\hline \hline Female & 30 & 36.5 \\
\hline \hline Total & 82 & 100 \\
\hline
\end{tabular}

Table (2): Frequency, distribution according to sector

\begin{tabular}{|c||c||c||}
\hline Sectors & Cases number & $\%$ \\
\hline \hline Tahrir & 22 & 26.8 \\
\hline \hline Alkatoon & 15 & 18.2 \\
\hline \hline Almualmeen & 10 & 12.1 \\
\hline New Baquba & 10 & 12.1 \\
\hline \hline Unrecorded & 25 & 30.4 \\
\hline \hline Total & 82 & 100 \\
\hline
\end{tabular}

Table (3): Frequency, distribution according to age

\begin{tabular}{|c||c||c|}
\hline \hline Years & Cases & $\%$ \\
\hline $1-5$ & 20 & 24.3 \\
\hline $6-8$ & 26 & 31.7 \\
\hline $9-12$ & 30 & 36.5 \\
\hline \hline Older & 6 & 7.3 \\
\hline Total & 82 & 100 \\
\hline \hline
\end{tabular}

Table (4): Frequency, distribution according to months

\begin{tabular}{|c||c||c|}
\hline Months & Cases & $\%$ \\
\hline \hline January & 32 & 39.02 \\
\hline \hline February & 25 & 30.4 \\
\hline \hline March & 20 & 24.3 \\
\hline \hline April & 5 & 6.09 \\
\hline May & 0 & 0 \\
\hline \hline June & 0 & 0 \\
\hline \hline July & 0 & 0 \\
\hline \hline Total & 82 & 100 \\
\hline
\end{tabular}

\section{Discussion}

In Chickenpox or Varicella is a viral disease caused by Varicella Zoster. The disease is more prevalent among children less than ten years [9]. More than $95 \%$ of adult person was infected with chickenpox in their 
childhood life. In non-vaccinated populations, primary infection tends to occur at a younger age while in adult may be more severe. Varicella may infect different mammals such as horses, monkeys, rabbits, sheep and cows [10]. The results of this study showed that the occurrence of Varicella in Iraq was (65.5 per 100.000) and this result was less than in other countries as Italy (6136 per 100.000)[11], also the incidence of disease in Iraq was less than Turkey (466-768 per 100.000)[12], and lower than in Iran[13]. Recent finding were supported by study in Diyala province of Iraq which found that the percent of infection with Varicella Zoster was $10.09 \%$ while in female was $6.51 \%$ [14]. Also the study in AL-Dora city (southern Baghdad)-Iraq the male cases were $(65.7 \%)$ and female cases were (34.3\%) [15].

The highest reported cases were observed in the AL-Thrir 22 cases(26.8\%), and ALKatoon 15 cases (18.2\%),In Iraq, geographic distribution of chickenpox cases was recorded by study in Ninawa (26.000 cases for 4 years), Baghdad /Russafa (245.000 cases for 4 years), Baghdad/ Karkh (21.000 cases for 4 years), AL-Basrah(20.000 cases for 4 years). The occurrence of varicella in Iraq is depending on geographic distribution. This occurrence is affected by climatic nature of country, virus survival, virus infectivity and cases registration [16]. It has been found the transmission of virus is reduced in the humid, hot climate [17].

Varicella is still a highly common childhood disease and may become more severe with age [18]. School children are a victim and target of Varicella because of weakened of the immune system in childhood may cause severe illness and even death [10].

This study was agreed with a study that showed the most of varicella cases were occurred in age group 5-14 years (65\%). Prevalence of Varicella among school children may be due to poor hygiene, social habits, and the chickenpox vaccine is not in program of Iraq immunization. In tropical countries the epidemiology of varicella is different, in these area a higher proportion of cases occur among adults [10].

Varicella appeared in winter months and disappeared in the summer months, seasonal distribution of varicella was reported by other studies which showed rising of cases in December and January. A recent study similar with other studies that recorded the low number of varicella in April and May $[15,16]$, and this finding similar to the results were reported in India [17].

\section{Conclusions}

It was concluded that Chickenpox more common in male.Highest infections were reported in winter months and disappear in the summer months. In addition, the prevalence of chickenpox among school children may correlate with many causes as, lack of rapid identification, the epidemiological situation of disease, deficiency of care facilities, and mass vaccination to uninfected persons.

\section{Recommendations}

It needs collaboration of (American Council for Immunization Program ACIP) with Ministry of Health in Iraq to put a clear plan of introducing the chickenpox vaccine into the immunization program . Also the national survey for the prevalence of markers 
of infection with Varicella Zoster should be conducted.

Source of funding: This research was funded by ourselves and these is no other funding cover this study or manuscript preparation and publication.

Ethical clearance: This study was approved by medical ethics committee of college of medicine, university of Diyala.

\section{Conflict of interest: Nill}

\section{References}

[1]McCrary ML, Severson J, Tyring SK.

Varicella zoster virus. J Am Acad Dermatol 1999; 41:1-14.

[2]James WD, Berger TG, Elston DM, Varicella. Andrew's Disease of skin the clinical Dermatology. 11thed. ELsevir INC. 2011; 19: 369-371.

[3]World Health Organization. Country Cooperation Strategy for WHO and Iraq 2012-2017. Documented WHOEM/PME/004/E/07.13.2013.PP:1-48.

[4]Communicable Disease Control Center. National state and local area vaccination coverage among adolescents aged 13-17 years. United states, 2009.Morbidity and Mortality Weekly Reported, 2010, 59(32). pp: 1018-1023.

[5]BOLONGIA JL, JORIZZO JL, SCHFFER JV. Human Herpes virus, Dermatology. $3^{\text {rd }}$ ed. ELSEVIER limited, 2012;80: 1328-1333. [6]Habif TP: Varicella. In Clinical Dermatology: A color Guide to Diagnosis and therapy, 5th ed. Edinburgh, UK, Mosby, 2010; 7:474-478.

[7]Chaves SS, Gargiullo P, Zhang JX, et aL loss of vaccine-induced immunity over time. N Engl J Med. 2007; 356:1121-9.
[8]Papaloukas O and Giannouli G. Successes and challenges in varicella vaccine. Ther Adv Vaccines, 2014, 2(2). pp: 39-55.

[9]Communicable Disease Control Center. Evolution of varicella surveillance-selected states, 2000-2010. Morbidity and Mortality Weekly Report 61(32).2012. pp: 609-612.

[10]Communicable Disease Control Center. Varicella Epidemiology and Prevention of Vaccine-Preventable Disease the Pink Book.Course Textbook, Thirteenth Edition,2015. pp: 353-376.

[11]Pozza F. Piovesan C. Russo F. Bella A. Pezzotti $\mathrm{P}$ and Emberti Gialloreti L. Impact of universal vaccination on the epidemiology of varicella in Veneto, Italy. vaccine ,29(51),2011. pp:9480-9487.

[12]Dinleyic EC, Kurugol Z, Turel O, Hatipoglu N,Devrim L,Agin L, and Akarsu $S$. The epidemiology and economic impact of varicella-related hospitalization in Turkey from 2008-2010: a nationwide survey during the pre-vaccine era (VARICOMP study). Euro Pean Journal Pediatrics, 171,2012. pp: 817-825.

[13]Sharifi $Z$ and Ghanjin E. The sero epidemiology of Varicella Zoster Virus in different age groups in Tehran, Iran. Iran J Allergy Asthma Immunol, 4,2005.pp: 95-98. [14]AL-Kayalli K.KH,Numman N.K, and AL-Qaisy M.H. Prevalence of Viral Skin Infections among patients in Diyala Province- Iraq. Diyala Journal of Medicine.2014. 6(1), pp:92-99.

[15]AL-Obaidi M.J, Ali H.A. Risk Factors for Varicella Prevalence among Primary School Children in AL-Dora city (southern Baghdad). Iraq; Journal of Science Vol.57, No. 2A,2016. pp: 830-837. 
[16]Khaleel H.A and Muslem H. Clinical Epidemiology of Chickenpox in Iraq from 2007-2011. Global Journal of Health Science.2013. 5(1), pp: 180-186.

[17]Lee B.W. Review of Varicella Zoster Sero-epidemiology in India and Southeast Asia. Tropical Medicine and International Health. 1998. 3(11), pp: 886-890.

[18]Masuet-Aumatell c. Ramon JM.

Casanova RA. Banque NM. Sero-Prevalence of Varicella-Zoster Virus infection in children from Cochabamba: tropical or temperate pattern? Tropical Medicine and International Health.2013. 18(3),pp: 296-302. 